there was no mistaking its identity. It flew away and I could not find it again. That was a thrill I will not forget for a long time.

A pleasant finale to the spring surprises was seeing a pair of American Goldfinches around our yard on July 6. These birds may not be uncommon here, but we have never seen them before.

In many ways this past spring was a late and discouraging one, but the bad weather was more than made up for by our unusual bird migration. I would be very interested to know how far north these species have been recorded in Saskatchewan and Alberta.

[EDITOR'S NOTE: Salt and Wilk (1966. Birds of Alberta) cite only one authenticated record of the Scarlet
Tanager for Alberta, that of a female that struck a window in Calgary on November 2, 1964, but they mention that sight records are occasionally reported. In Saskatchewan, the farthest north records of the species are sight records from Yorkton (1950), Young (1963), and Saskatoon (1965). See Margaret Belcher's article "The status of the Scarlet Tanager in Saskatchewan" (Blue Jay 23:117119) and the report by Gollop, Slimmon and Folker "Some 1965 bird records for the Saskatoon district" (Blue Jay, 24:76-78).

Discussion of this Norway House record of the Scarlet Tanager with Dr. Robert W. Nero, now at the Manitoba Museum of Man and Nature, confirms that this must be considered the northernmost record known for the species.]

\title{
ANNUAL MAY BIRD COUNT, SASKATOON
}

by J. F. Roy, 120 Maple Street, Saskatoon

On May 27, 1967, 29 observers in six groups established a new record of 145 species seen in a single day in the Saskatoon study area, a square block consisting of 100 townships $(3,600$ square miles) centering on Saskatoon. The previous high had been set last year when 140 species were observed. It was an excellent day for field observations, with mostly sunny skies and the temperature ranging from $45^{\circ}$ to $74^{\circ}$. Apart from a brief period of gusty southeast winds between noon and 2:00 p.m., the winds remained light.

Once again the southeast proved to be the most rewarding corner ornithologically; here, groups led by J. B. Gollop and J. A. Wedgwood observed 118 species. The southwest produced 113 species, the northeast, 102, and the northwest 98. Among the highlights of the count were a Common Loon on Moon Lake; a flock of eight late Whistling Swans on Rice Lake and one individual in the northeast; two separate sightings of the Piping Plover; a pair of Buff-breasted Sand- pipers near Buffer Lake; and two new breeding records for the Saskatoon region: the Common Goldeneye and the Blue Jay, both nests being discovered by Jim Slimmon in the northwest sector. The Chukar was found near the Forestry Farm sitting on top of a barn.

Once again warbler numbers proved disappointing, only 11 species being identified. The count was just a few days too late to include the migrant sparrows. No White-crowned, Lincoln, Fox, Swamp or Harris' Sparrows were recorded, and only single individuals of the White-throated Sparrow and the Slate-coloured Junco.

On the day following this count, a new species for the district (McCown's Longspur) was found in an area not visited on May 27. This suggests that more thorough coverage, requiring more independent parties with at least one reliable observer in each, is required for a more complete enumeration of the birds present on the May count. 


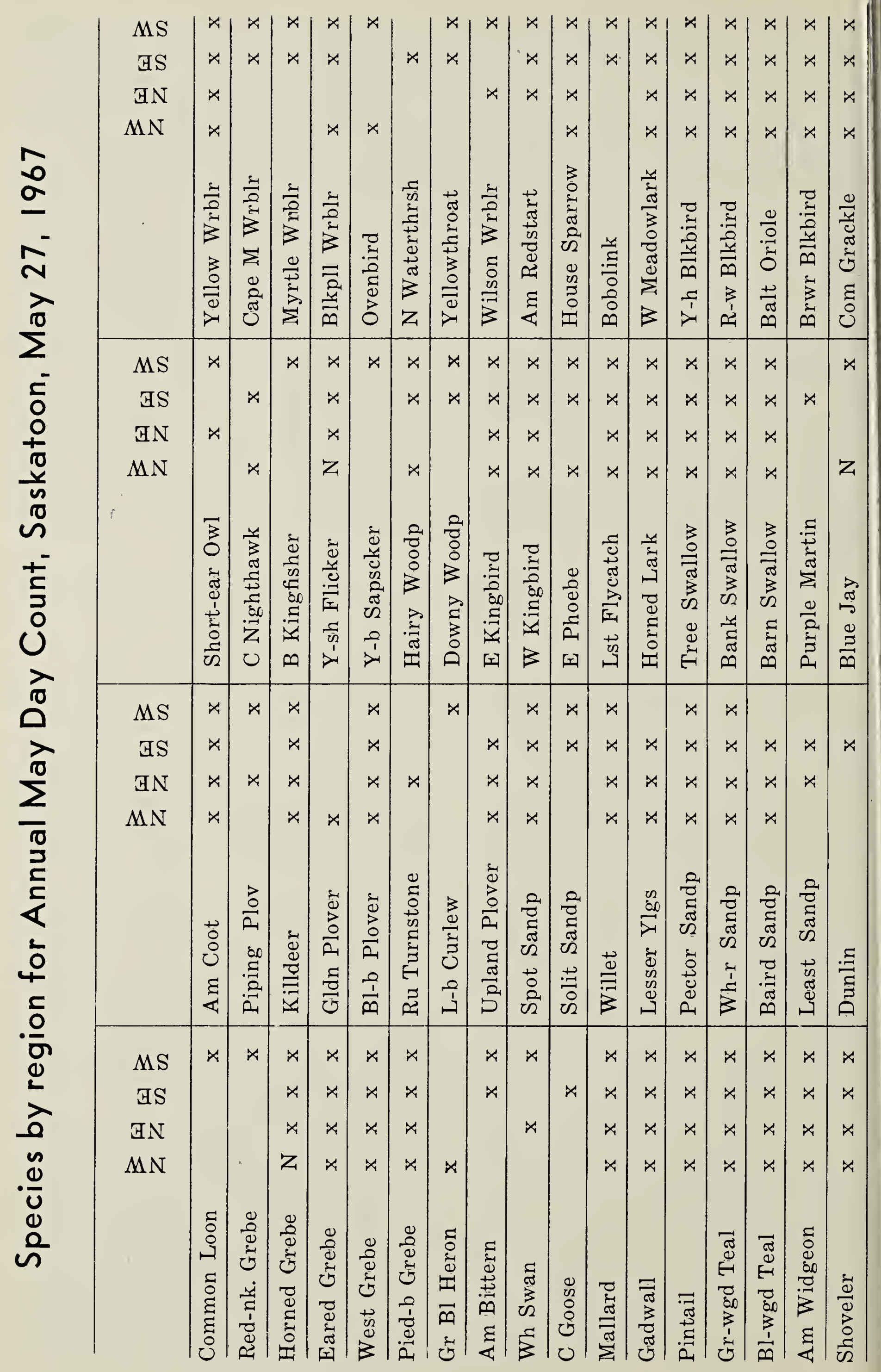


